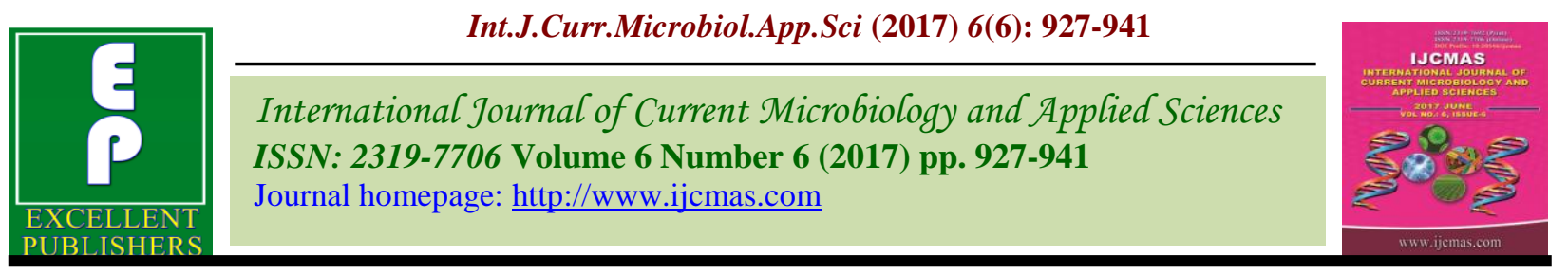

Original Research Article

https://doi.org/10.20546/ijcmas.2017.606.109

\title{
Characterization of $\beta$-Lactamase from Two Pathogenic Bacteria
}

\author{
Hamed M. El-Shora ${ }^{*}$, Huda S. Al-Hayanni* and Ahmed M. El-Shobaky ${ }^{1}$ \\ ${ }^{1}$ Botany Department, Faculty of Science, Mansoura University, Egypt \\ ${ }^{2}$ Biology Department, College of Science for Women, University of Baghdad, Iraq \\ *Corresponding author
}

\begin{tabular}{|c|c|}
\hline & A B S T R A C T \\
\hline & \multirow{6}{*}{$\begin{array}{l}\text { Beta-lactamase (EC 3.5.2.6) was isolated and purified from two clinical } \\
\text { isolates of Staphylococcus sciuri and Klebsiella pneumoniae by several steps } \\
\text { included precipitation with ammonium sulphate at } 80 \% \text { saturation, DEAE- } \\
\text { Cellulose and gel filtration on Sephadex G- } 200 \text { column. The characterization } \\
\text { of the purified } \beta \text {-lactamase showed that the molecular weight was } 30 \mathrm{KDa} \text { for } \\
S \text {. sciuri } \beta \text {-lactamase, and } 28 \mathrm{KDa} \text { for purified } K \text {. pneumoniae } \beta \text {-lactamase as } \\
\text { estimated by sodium dodecyl-sulphate polyacrylamide gel electrophoresis } \\
\text { (SDS-PAGE). The purified enzyme from } S \text {. sciuri and } K \text {. pneumonae has an } \\
\text { optimal temperatures of } 35^{\circ} \mathrm{C} \text { and } 40^{\circ} \mathrm{C} \text {, respectively. The enzyme from } S \text {. } \\
\text { sciuri was more stable than that of } K . \text { pneumoniae. The optimal pH value were } \\
7.0 \text { and } 6.0 \text { from } S \text {. sciuri and K. pneumoniae, respectively. The best } \\
\text { concentrations of penicillin G were } 400 \mu \mathrm{g} \text { ml- and } 500 \mu \mathrm{g} \text { ml- } 1 \text { for the } \\
\text { enzyme from } S \text {. sciuri and } K \text {. pneumoniae. The increase in the enzyme } \\
\text { concentration resulted in continuous increase in its activity from both bacteria. }\end{array}$} \\
\hline Keywords & \\
\hline $\begin{array}{l}\text { 3-lactamase, } \\
\text { Staphylococcus } \\
\text { sciuri, Klebsiella }\end{array}$ & \\
\hline $\begin{array}{l}\text { Purification, } \\
\text { Characterization, } \\
\text { Kinetic parameters. }\end{array}$ & \\
\hline Artic & \\
\hline epted: & \\
\hline
\end{tabular}

\section{Introduction}

Enzymes occur in all living cells, hence in all microorganisms. Each single strain of organism produces a large number of enzymes, oxidizing, hydrolyzing or reducing and metabolic in nature (El-Shora and Ashour, 1993; El-Shora and Metwally, 2008).

The increase in antimicrobial resistance for pathogenic bacteria is represents major problem over the last decade (Gniadkowski, 2001). Among the multidrug resistant pathogens are Klebsiella pneumoniae, Escherichia coli, Acinetobacter baumannii and Staphylococcus aureus represents an example of methicillin-resistant. Streptococcus pneumoniae is penicillinresistant and vancomycin-resistant Enterococcus. However, Mycobacterium tuberculosis is extensively drug-resistant (Alekshun and Levy, 2007).

Beta-lactamases production is an important mechanism of bacterial resistance to $\beta$-lactam antibiotics. $\beta$-lactam drugs inhibited the last sage of bacterial cell wall synthesis and they are the largest family of antimicrobial agents (Suarez and Gudiol, 2009). $\beta$-lactamases destroyed the utility of benzyl penicillin against Staphylococci. New enzymes and new 
modes of production of old enzymes now threaten the value of cephalosporins against Enterobacter (Livermore, 1995). Since cephalosporins, penicillins, and carbapenems are included in the preferred treatment regimens for many infectious diseases, the presence and characteristics of these enzymes play a critical role in the selection of appropriate therapy (Bush and Jacoby, 2010).

There are three major groups of the above enzymes. They are class $\mathrm{C}$ cephalosporinase (AmpC), extended-spectrum $\beta$-lactamases (ESBL) and different types of $\beta$-lactamases with carbapenemase activity of which so called metal lo- $\beta$-lactamases (MBLs), are of great concern (Helfaut and Bonomo, 2005).

The aim of the present work to purify and characterize $\beta$-lactamase from two clinical isolates: Gram-positive S. sciuri and Gramnegative $K$. pneumoniae.

\section{Materials and Methods}

\section{Bacterial isolates}

The two bacterial isolates (Gram-positive and Gram- negative) used in the present investigation were obtained from laboratory of clinical microbiology of the Faculty of Medicine at Mansoura University from clinical specimens of patients. The two bacterial isolates were subjected to screening tests for $\beta$-lactamase production by phenotypic methods (iodometric method and acidimetric method) according to Livermore and Brown (2001) and were given a fast positive results (immediately result within 20-30 seconds).

The identification of the two isolates was carried out using Microscan Walk A way system (2013 Siemens Healthcare Diagnostics Inc., UK) using dried Gram-positive and Gram-negative panels which designed for use in identification to the species level and antimicrobial susceptibility testing by determining Minimum Inhibitory Concentration (MIC). This diagnosis was carried out in microbial laboratory of Mansoura University hospital for children, and the results proved two isolates Staphylococcus sciuri and Klebsiella pneumoniae. Other detection methods of $\beta$ lactamase were applied on S. sciuri and $K$. pneumoniae to make sure that these isolates producing $\beta$-lactamase which include: antibiotic susceptibility test and molecular detection of $\beta$-lactamase encoding genes by polymerase chain reaction (PCR) for both bacteria.

\section{Isolation of crude $\beta$-lactamase}

$\beta$-lactamase was isolated from two clinical isolates $S$. sciuri and $K$. pneumoniae. The isolation was carried out according to Hedberg et al., (1995) with slight modification. Bacterial isolates were grown overnight in $100 \mathrm{ml}$ brain heart infusion (BHI) broth at $37^{\circ} \mathrm{C}$ then diluted 10 -fold with the fresh brain heart infusion broth.

The culture was incubated with shaking at $37^{\circ} \mathrm{C}$. After $1.5 \mathrm{~h}$ of incubation, the penicillin $\mathrm{G}$ was added to final concentration of $100 \mu \mathrm{g}$ $\mathrm{ml}^{-1}$ for enzyme induction. The incubation was continued for $4 \mathrm{~h}$. The bacterial cells were collected by centrifugation at $5000 \mathrm{~g}$ for $15 \mathrm{~min}$ at $4^{\circ} \mathrm{C}$, washed twice with $50 \mathrm{mM}$ $\mathrm{Na}_{2} \mathrm{HPO}_{4} / \mathrm{KH}_{2} \mathrm{PO}_{4}$, ( $\mathrm{pH} 7.0$ ), and suspended the same buffer. The suspension was disrupted by ultra-sonicater in an ice-water bathfor $15 \mathrm{~min}$. The disrupted cell suspension was centrifuged at $5000 \mathrm{~g}$ at $4^{\circ} \mathrm{C}$ for 15 min.The resulting supernatant represents the crude enzyme extract which was stored at $20^{\circ} \mathrm{C}$ until use.

\section{Beta-lactamase purification}

The purification of the crude enzyme extracts 
of S. sciuri and K. pneumoniae was carried out at $4^{\circ} \mathrm{C}$.

\section{Ammonium sulphate precipitation}

Partial purification of the crude $\beta$-lactamase was carried out by adding of ammonium sulphate up to $80 \%$ saturation at $4^{\circ} \mathrm{C}$. The mixture was stored at $4^{\circ} \mathrm{C}$ overnight followed by centrifuging under cooling at $5000 \mathrm{~g}$ for 15 min. The precipitated protein was dissolved in a $50 \mathrm{mM}$ phosphate buffer $(\mathrm{pH}$ 7.0) and stored for further purification at $4^{\circ} \mathrm{C}$.

\section{DEAE-cellulose chromatography}

The enzyme from the above step was applied to DEAE-Cellulose column $(2.5 \times 20 \mathrm{~cm})$ that was pre-equilibrated with $50 \mathrm{mM}$ phosphate buffer (pH 7.0). The dialyzed fraction was layered carefully on the top of gel under cooling condition. The protein elution was done with the same buffer at a flow rate of $2 \mathrm{ml} / 1 \mathrm{~min}$. The fractions were collected and the active fractions were pooled and concentrated by dialysis using $50 \mathrm{mM}$ phosphate buffer $(\mathrm{pH}$ 7.0).

\section{Gel-filtration chromatography}

The concentrated DEAE-Cellulose dialyzed sample was applied to Sephadex G-200 column $(2.5 \times 20 \mathrm{~cm})$ at $4^{\circ} \mathrm{C}$, equilibrated and eluted with $50 \mathrm{mM}$ phosphate buffer (pH 7.0). Fractions were collected and analyzed for protein estimation at $280 \mathrm{~nm}$ and $\beta$-lactamase activity at $620 \mathrm{~nm}$.

\section{Estimation molecular weight of $\beta$ - lactamase}

The purity and the molecular weight of $\beta$ lactamase preparation following gel filtration chromatography were estimated by sodium dodecyl-sulphate polyacrylamide gel electrophoresis (SDS-PAGE) according to the method of Laemmli (1970).

\section{Effect of different $\mathrm{pH}$ values on $\beta$ - lactamase activity}

This experiment was carried out at various $\mathrm{pH}$ values $(3,4,5,6,7,8,9$ and 10$)$. The enzyme solution was adjusted using sodium acetate buffer ( $\mathrm{pH} 4$ to 6), phosphate buffer ( $\mathrm{pH} 7$ ), and Tris-buffer ( $\mathrm{pH} 8,9,10)$. The enzyme activity was measured at $620 \mathrm{~nm}$. The relation between $\mathrm{pH}$ values and enzyme activity was plotted.

\section{Heat stability of $\beta$-lactamase}

One $\mathrm{ml}$ of enzyme solution was added in test tubes and incubated in water-bath at different temperatures (from $20^{\circ} \mathrm{C}$ to $90^{\circ} \mathrm{C}$ in the scale of 5 degree) for $15 \mathrm{~min}$. The test tubes were then cooled directly in ice-bath, and the remaining activity was determined. The relation between temperature and the percentage of remaining enzyme activity was plotted.

\section{Effect of incubation time on stability of $\beta$ - lactamase}

The enzyme solution was incubated at $45^{\circ} \mathrm{C}$ for different time intervals $(10,20,30,40,50,60$ and $120 \mathrm{~min}$ ), and cooled directly in ice -bath. The remaining enzyme activity was determined and the relation between different time intervals and the enzyme activity was plotted.

\section{Effect of different substrate concentrations on $\beta$-lactamaseactivity}

Substrate concentration was tested at a range of $100-500 \mu \mathrm{g} \mathrm{ml}-1$. The assay mixture contained $2.91 \mathrm{ml}$ of $50 \mathrm{mM}$ phosphate buffer ( $\mathrm{pH} 7.0$ ), $40 \mu \mathrm{l}$ of penicillin $\mathrm{G}(100-500 \mu \mathrm{g} \mathrm{ml}-1)$ and 50 $\mu l$ of enzyme. The decrease in absorption at 620 $\mathrm{nm}$ against a reference containing only the enzyme in the buffer was recorded.

\section{Determination of the kinetic parameters of $\beta$-lactamase (Km, Vmax)}

The kinetic values of the free $\beta$-lactamase were calculated from Lineweaver - Burk plots 
(Palmer, 1995). The Michaelis-Menten's constant $(\mathrm{Km})$ and the maximum attainable velocity (VMax) were determined by investigating the effect of different substrate concentrations on enzyme activity. Enzyme activity was determined at different substrate (S) concentrations. The Lineweaver-Burk plot $(1 / \mathrm{V}$ vs $1 / \mathrm{S}$, where $\mathrm{V}$ is the reaction velocity) was then constructed, and from this graph, the $\mathrm{Km}$ and $\mathrm{V}_{\max }$ were determined for $\beta$-lactamase.

\section{Effect of different enzyme concentrations on $\beta$-lactamase activity}

The assay mixture contained $(2.91 \mathrm{ml}$ of $50 \mathrm{mM}$ phosphate buffer ( $\mathrm{pH} 7.0), 40 \mu \mathrm{l}$ of penicillin $\mathrm{G}$, and different volumes of enzyme $(0.1,0.2,0.4$, 0.6, 0.8 and $\left.1.0 \mu \mathrm{g} \mathrm{ml}^{-1}\right)$. The decrease in absorption at $620 \mathrm{~nm}$ against a reference containing only the substrate in the buffer was recorded.

\section{Storage stability of $\beta$-lactamase}

This experiment was carried out by storing the purified enzyme solution at $4^{\circ} \mathrm{Cand}-20^{\circ} \mathrm{C}$ for 7 , 14, 21, 28, 35 and 42 days. The residual enzyme activity was determined after each period.

\section{Results and Discussion}

\section{Beta-lactamase Purification}

$\beta$-lactamase of $S$. sciuri and $K$. pneumoniae were purified using schedule including ammonium sulfate precipitation, DEAECellulose and Sephadex G-200. The results of purification are shown in Tables 1 and 2. The specific activities were 70 and 100 units $\mathrm{mg}_{-1}$ protein for the enzyme from $S$. sciuri and $K$. pneumoniae.

\section{Elution profile of $\beta$-lactamase}

The profile of purification contained 17 fractions and in each fraction the enzyme activity and the protein concentration were determined as in Figs. 1 and 2. It was observed that the fraction number 11 expressed the highest activity and the highest protein content.

\section{Estimation molecular weight of $\beta$ - lactamase}

The purity of $\beta$-lactamase was examined and the molecular weight was determined from both $S$. sciuri and $K$. pneumonae using SDSPAGE and the results demonstrated the presence of a single protein band for both bacteria (Fig. 3). The molecular weight of the purified $\beta$-lactamase was $30 \mathrm{KDa}$ for $S$. sciuri $\beta$-lactamase and $28 \mathrm{KDa}$ for $K$. pneumonae enzyme (Fig. 3).

\section{Effect of different pH values on $\beta$ - lactamase activity}

The results in Fig. 4 showed that there was a gradually increase in $\beta$-lactamase activity with increasing $\mathrm{pH}$ values up to $\mathrm{pH} 7.0$ and $\mathrm{pH} 6.0$ for $\beta$-lactamase from $S$. sciuri and $K$. pneumonae, respectively which seem likely to be the optimum values after which there was a gradual decline in the enzyme activity of both bacteria.

\section{Effect of temperature on $\beta$-lactamase activity}

The results in Fig. 5 showed that by increasing the incubation temperature there was a corresponding increase in $\beta$-lactamase activity up to $35^{\circ} \mathrm{C}$ and $40{ }^{\circ} \mathrm{C}$ for the enzyme from $S$. sciuri and $K$. pneumonae, respectively.

\section{Heat stability of $\beta$-lactamase}

The results in Fig. 6 indicate that the enzyme activity at ${ }^{\circ} \mathrm{C}$ was reduced gradually through $100 \mathrm{~min}$ but the enzyme from $S$. sciuri was more stable than that from $K$. pneumoniae. 
Effect of incubation time on stability of $\beta$ lactamase

The results in Fig. 7 indicate that the activity decreased gradually with increasing the incubation time from $10 \mathrm{~min}$ to $120 \mathrm{~min}$. This was observed for both types of bacteria under the same experimental conditions.

\section{Effect of different substrate concentrations on $\beta$-lactamase activity}

The results in Fig. 8 indicated that the increase in the substrate concentration led to a corresponding increase in $\beta$-lactamase activity up to $400 \mu \mathrm{g}$ ml-1 for $S$. sciuri $\beta$-lactamase and $500 \mu \mathrm{g} \mathrm{ml}-1$ for $K$. pneumoniae $\beta$ lactamase.

\section{Determination of $\mathbf{K m}$ and $\mathbf{V}_{\max }$}

The initial velocity of $\beta$-lactamase reaction was measured as a function of substrate concentration and plotted as double reciprocal plot with substrate concentration in accordance with the Lineweaver-Burk analysis. The $\mathrm{Km}$ values were 175.43 and $222.22 \mu \mathrm{g} \mathrm{ml}-1$ for the enzyme from $S$. sciuri and $K$. pneumoniae, respectively. $\mathrm{V}_{\max }$ values were 7.69 and 8.33 units $\mathrm{mg}-1$ protein for both bacteria in the same order (Figs. 9 and $10)$.

\section{Effect of different enzyme concentrations on $\beta$-lactamase activity}

The results in Fig. 11 showed that increasing the enzyme concentration resulted in continuous increase in the enzyme activity for both bacteria.

\section{Storage stability of $\beta$-lactamase}

The results shown in Fig. 12 demonstrated that the $S$. sciuri $\beta$-lactamase retained $73.2 \%$ of its activity when stored at $-20^{\circ} \mathrm{C}$ for a period of 28 days, compared to $21.3 \%$ at $4^{\circ} \mathrm{C}$ for the same period. However, the enzyme lost its activity after 42 days at $4^{\circ} \mathrm{C}$ and retained $31.5 \%$ when stored at $-20^{\circ} \mathrm{C}$ for the same period. However, the remaining activity of $K$. pneumoniae $\beta$-lactamase (Fig. 13) was $46 \%$ at $-20^{\circ} \mathrm{C}$ for a period of 28 days compared to $12 \%$ at $4^{\circ} \mathrm{C}$ for the same period, but after 42 days it is inhibited competly at $4^{\circ} \mathrm{C}$ and retained $17 \%$ of its activity on storing at $-20^{\circ} \mathrm{C}$ for the same period.

Table.1 Summary of the purification of S. sciuri $\beta$-lactamase

\begin{tabular}{|c|c|c|c|c|c|}
\hline Purification & $\begin{array}{c}\text { Total } \\
\text { protein } \\
(\mathbf{m g})\end{array}$ & $\begin{array}{c}\text { Total } \\
\text { activity } \\
(\mathbf{U})\end{array}$ & $\begin{array}{c}\text { Specific activity } \\
\left(\mathbf{U ~ m g}^{-1} \text { protein) }\right.\end{array}$ & $\begin{array}{c}\text { Purification } \\
\text { fold }\end{array}$ & $\begin{array}{c}\text { Yield } \\
(\%)\end{array}$ \\
\hline Crude enzyme & 1400 & 2100 & 1.5 & 1.0 & 100 \\
\hline $\begin{array}{c}\text { Ammonium sulfate } \\
(75 \%)\end{array}$ & 540 & 1400 & 2.6 & 1.7 & 66.7 \\
\hline DEAE-Cellulose & 130 & 1000 & 7.7 & 5.1 & 47.6 \\
\hline SephadexG-200 & 10 & 700 & 70 & 46.7 & 33.3 \\
\hline
\end{tabular}


Table.2 Summary of the purification of K. pneumoniae $\beta$-lactamase

\begin{tabular}{|c|c|c|c|c|c|}
\hline Purification & $\begin{array}{c}\text { Total } \\
\text { protein } \\
(\mathbf{m g})\end{array}$ & $\begin{array}{c}\text { Total } \\
\text { activity } \\
(\mathbf{U})\end{array}$ & $\begin{array}{c}\text { Specific activity } \\
\left(\mathbf{U ~ m g}^{-1} \text { protein) }\right.\end{array}$ & $\begin{array}{c}\text { Purification } \\
\text { fold }\end{array}$ & $\begin{array}{c}\text { Yield } \\
(\%)\end{array}$ \\
\hline Crude enzyme & 1320 & 1600 & 1.2 & 1.0 & 100 \\
\hline $\begin{array}{c}\text { Ammonium sulfate } \\
(75 \%)\end{array}$ & 340 & 1200 & 3.5 & 2.9 & 75 \\
\hline DEAE-Cellulose & 80 & 850 & 10.6 & 8.8 & 53 \\
\hline Sephadex G-200 & 5 & 500 & 100 & 83.3 & 31 \\
\hline
\end{tabular}

Fig.1 Fractions of $\beta$-lactamase from $S$. sciuri

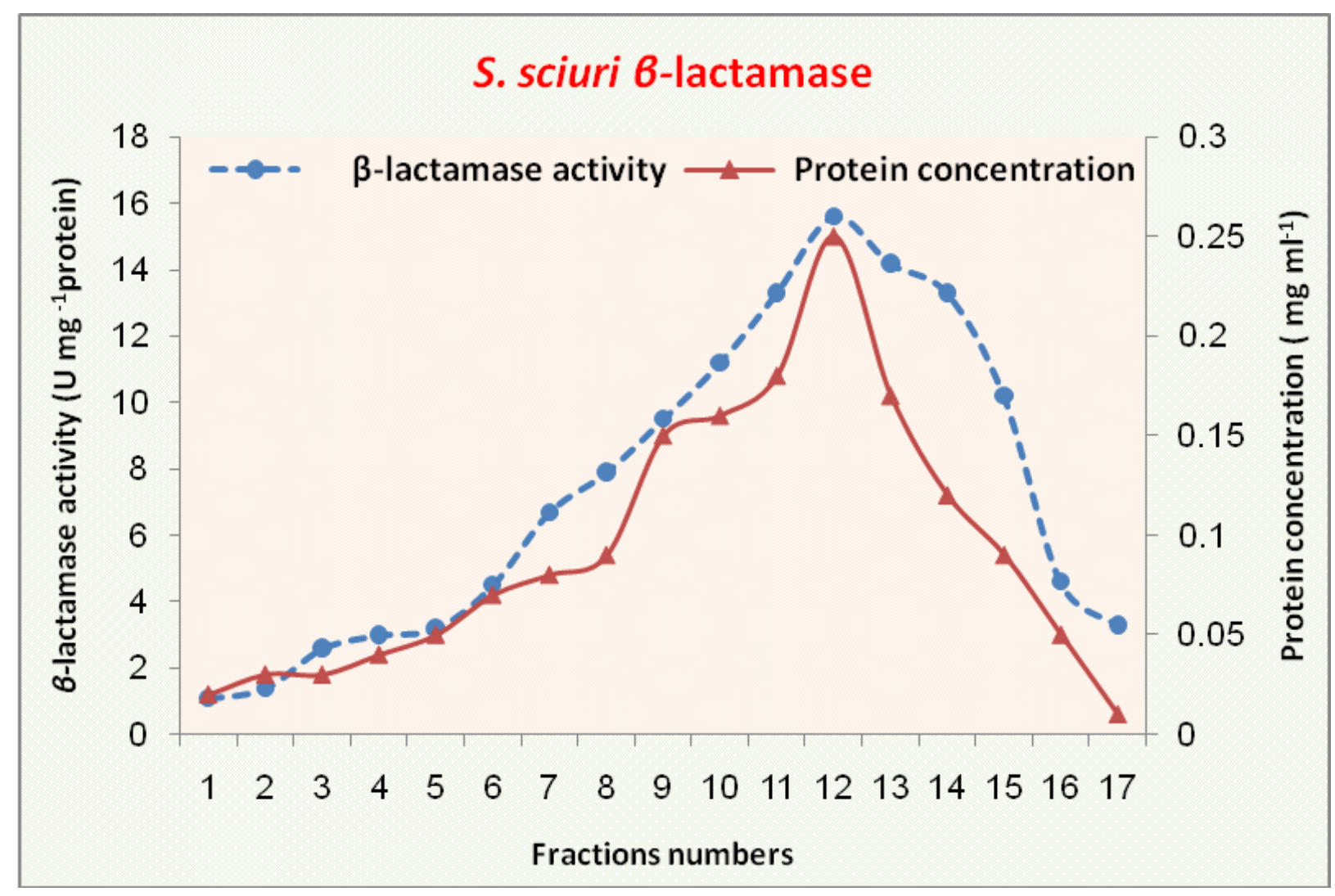


Fig.2 Fractions of $\beta$-lactamase from $K$. pneumoniae

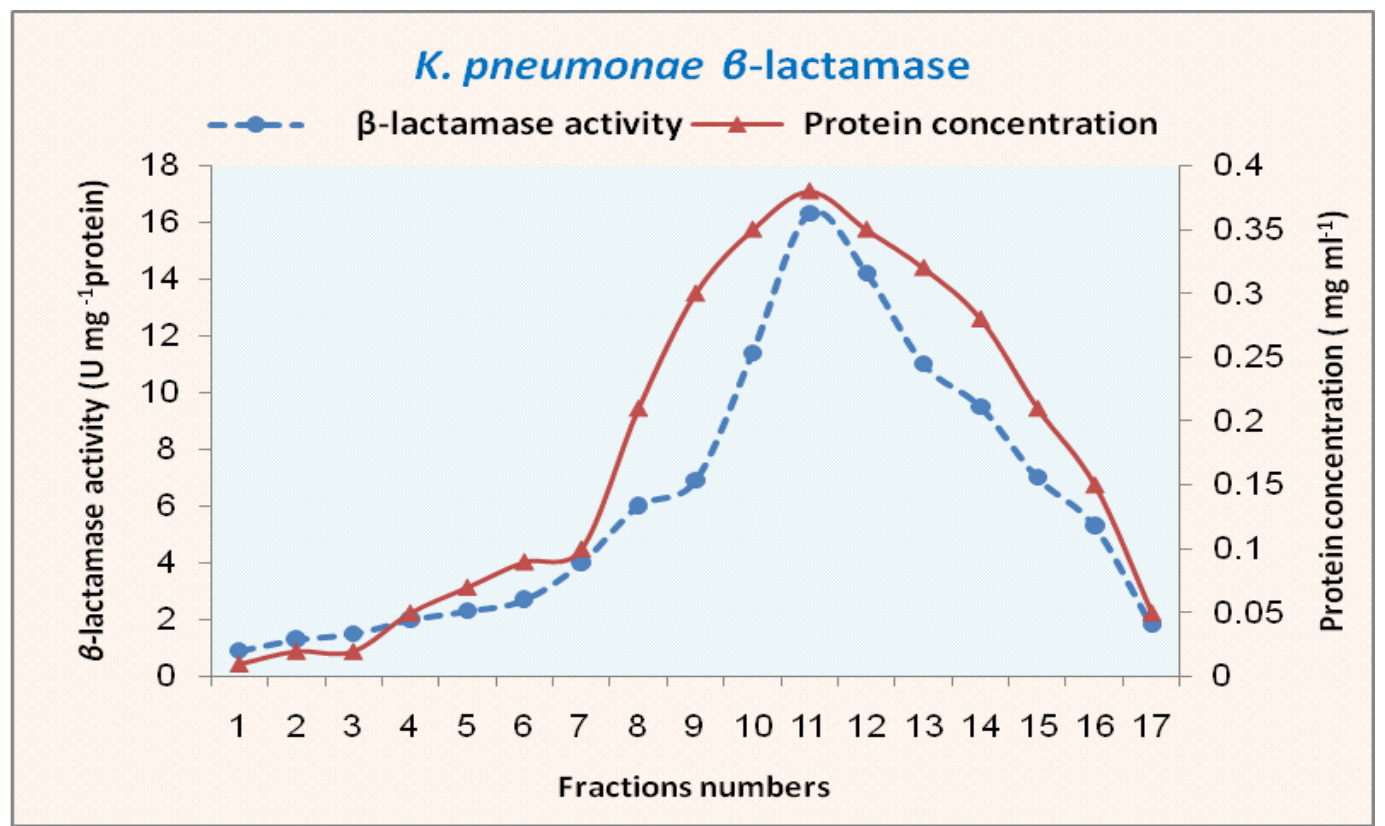

Fig.3 SDS-PAGE profiling of the purified $S$. sciuri and $K$. pneumoniae $\beta$-lactamase. $\mathrm{M}=$ Protein markers (in kilo daltons; molecular weight standards), Lane 1= purified $S$. sciuri $\beta$-lactamase; lane $2=$ purified $K$. pneumoniae $\beta$-lactamase

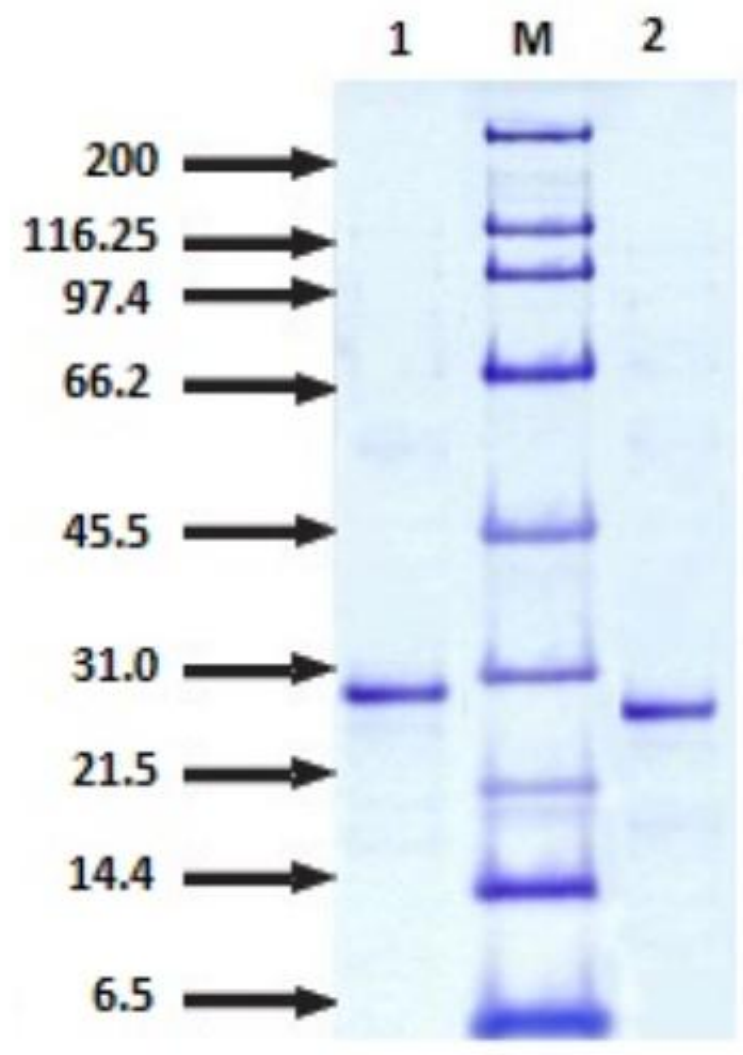


Fig.4 Effect of different $\mathrm{pH}$ values on $S$. sciuri and $K$. pneumonia $\beta$-lactamase activity

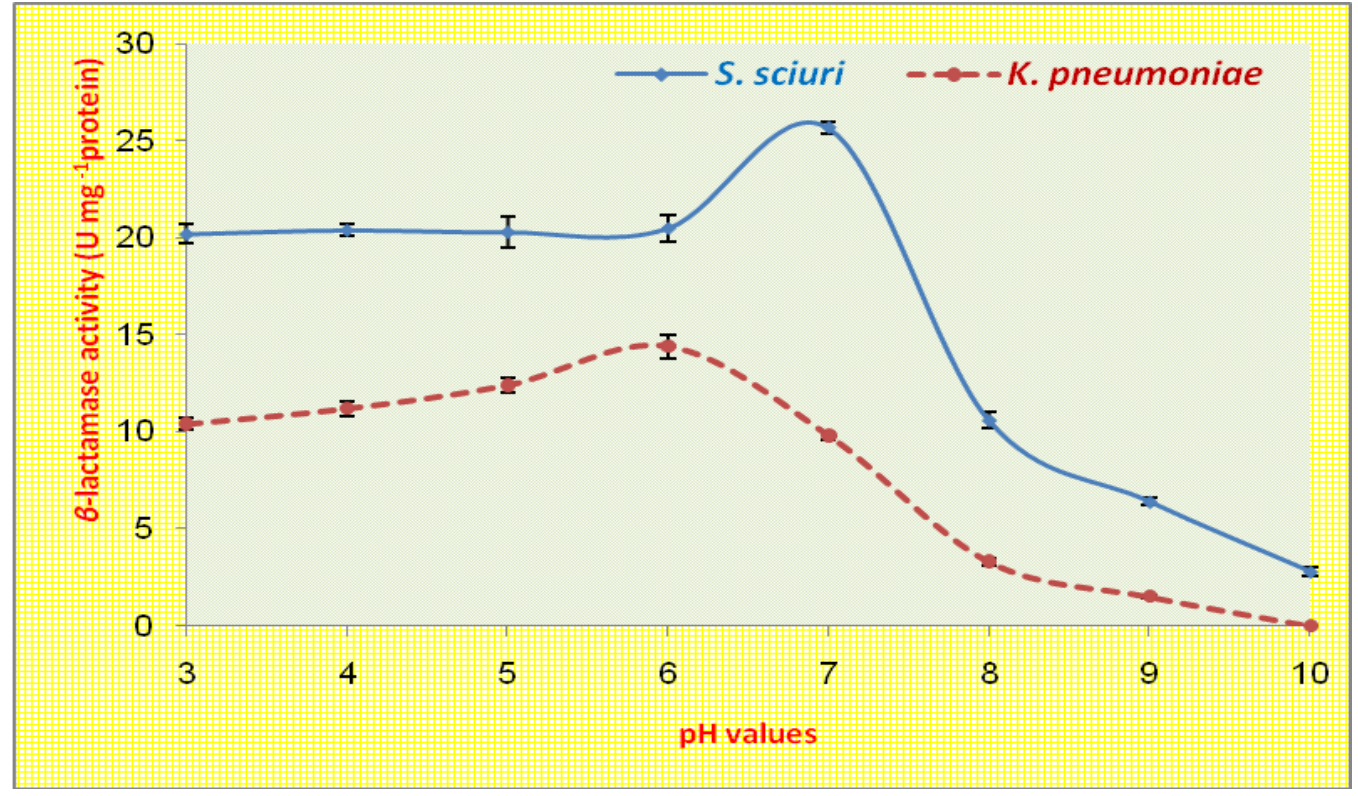

Fig.5 Effect of temperature on S. sciuri and K. pneumonia $\beta$-lactamase

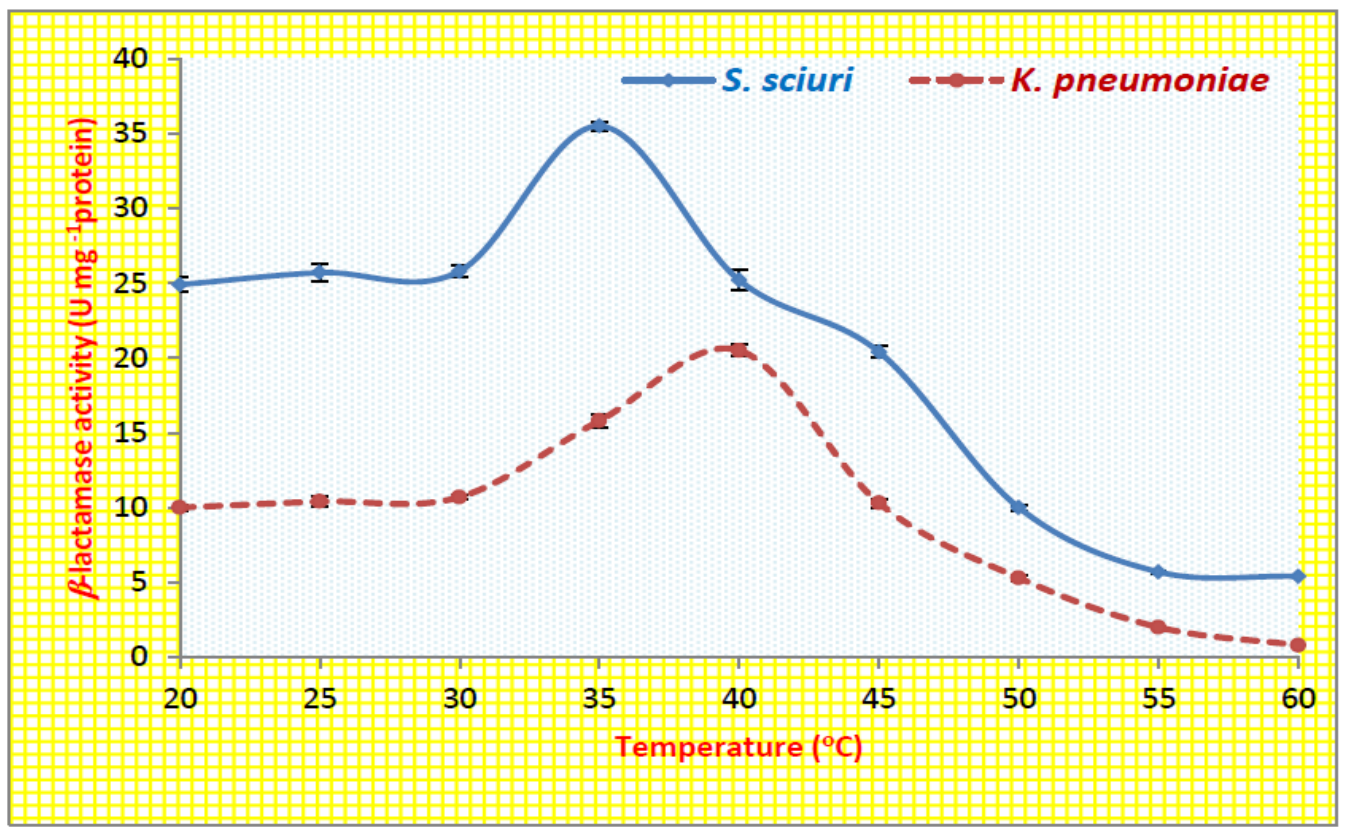


Fig.6 Thermostability of $S$. sciuri and $K$. pneumoniae $\beta$-lactamase at $45^{\circ} \mathrm{C}$.

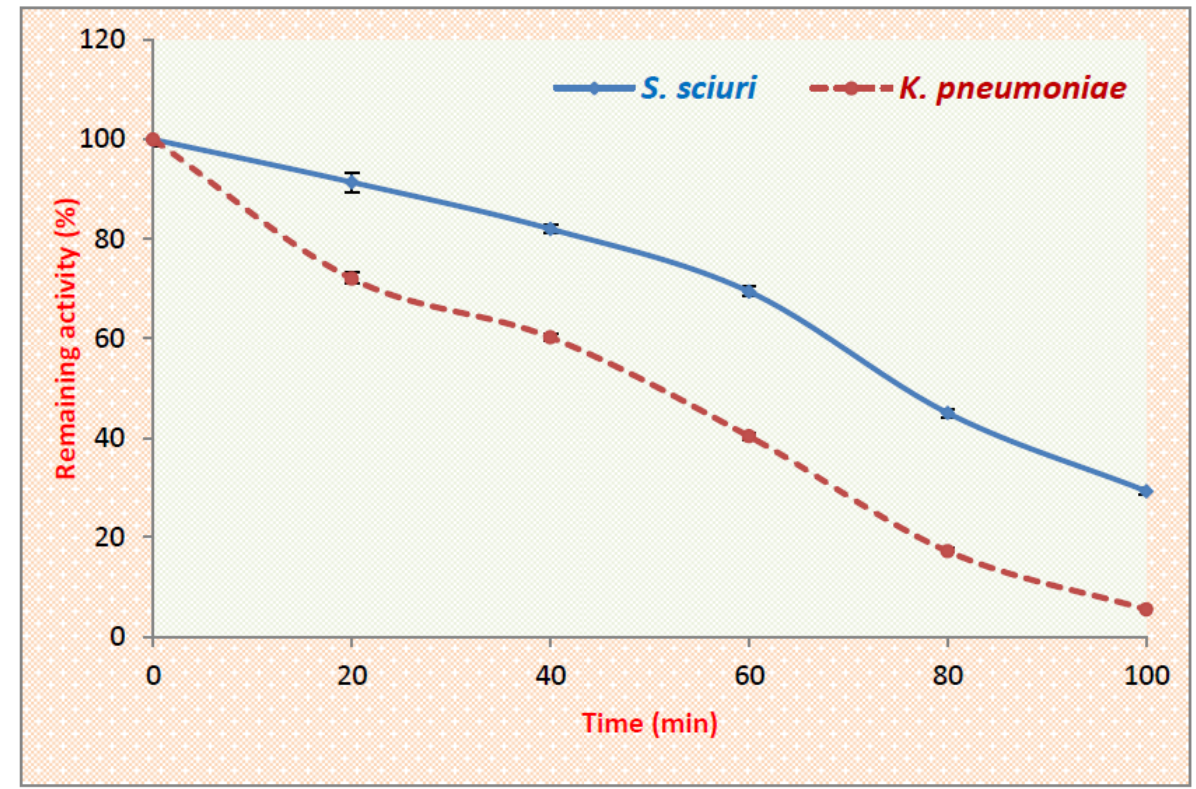

Fig.7 Effect of incubation time on $S$. sciuri and $K$. pneumonia $\beta$-lactamase activity

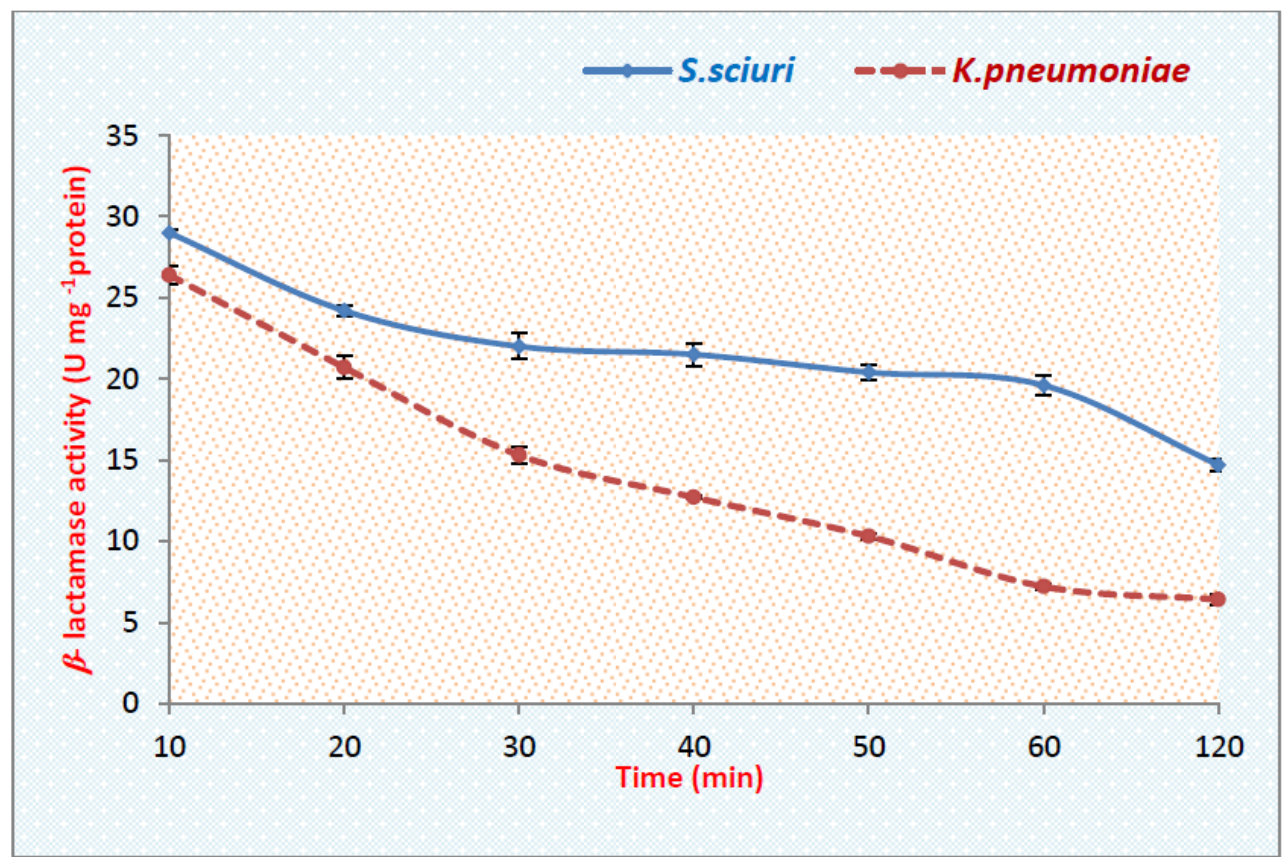


Fig.8 Effect of different substrate concentrations on S. sciuri and K. pneumoniae $\beta$-lactamase activity

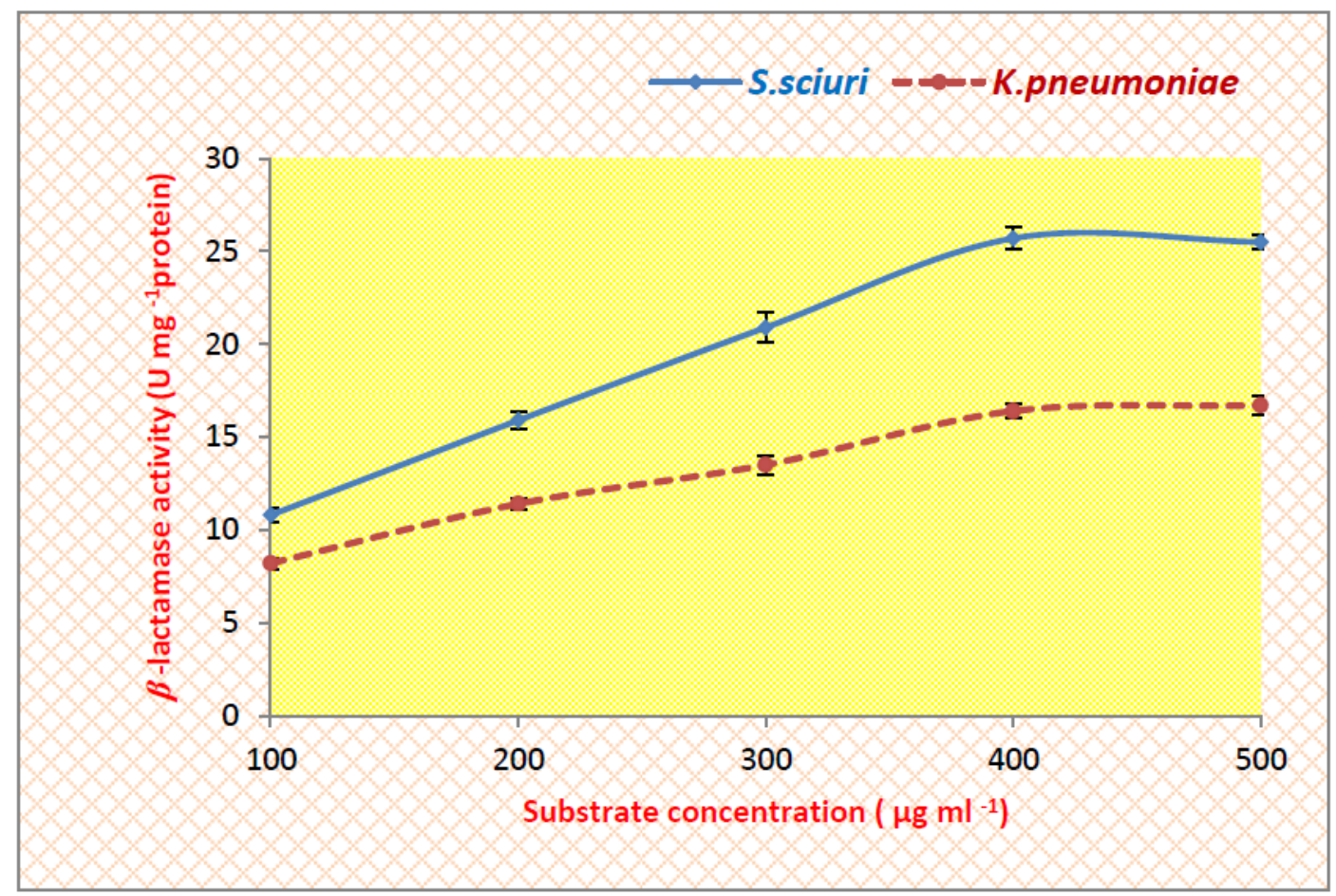

Fig.9 Reciprocal of V against reciprocal of $\mathrm{S}$ for $\beta$-lactamase from $S$. sciuri (Lineweaver-Burk plot).

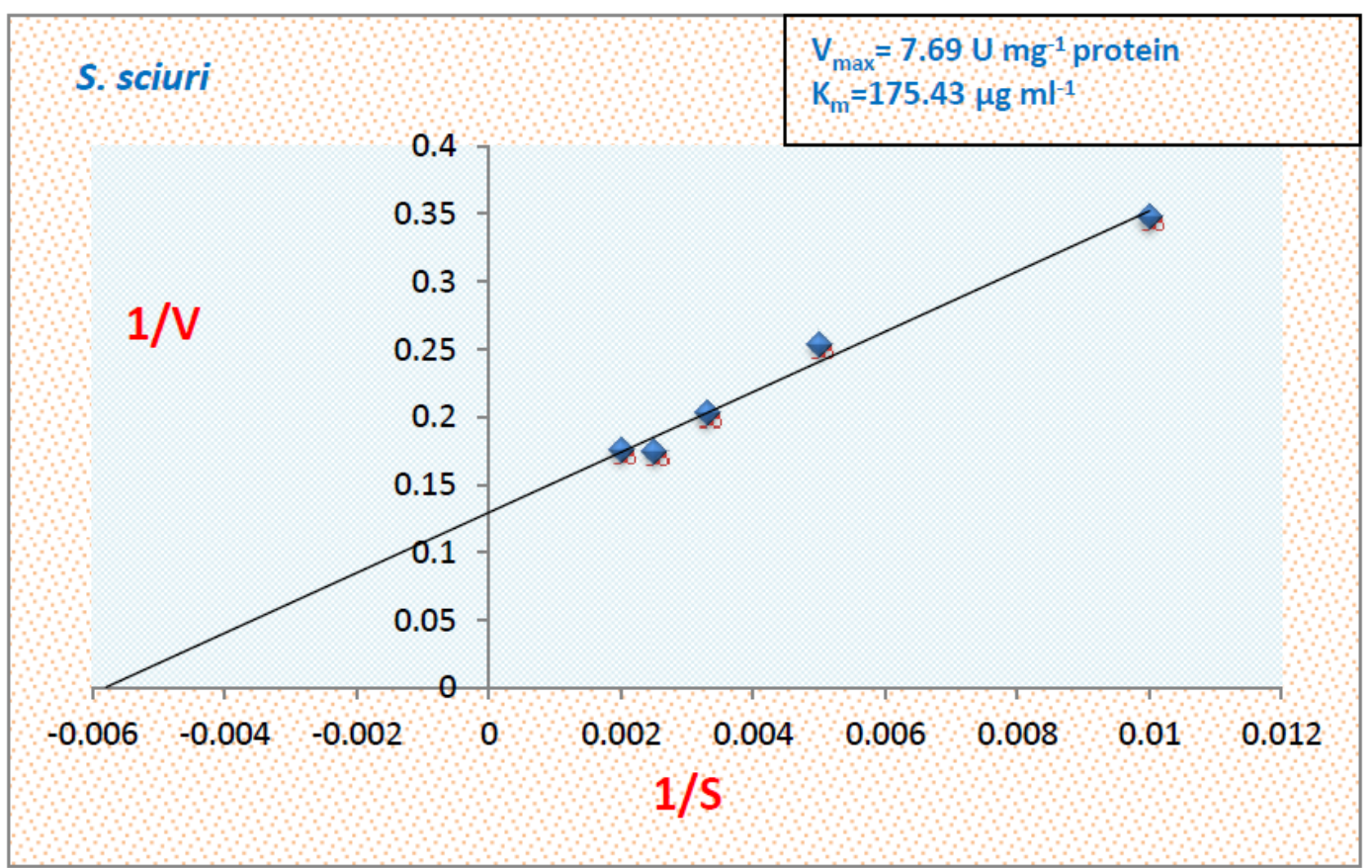


Fig.10 Reciprocal of $\mathrm{V}$ against reciprocal of $\mathrm{S}$ for $\beta$-lactamase from $K$. pneumoniae (Lineweaver-Burk plot).)

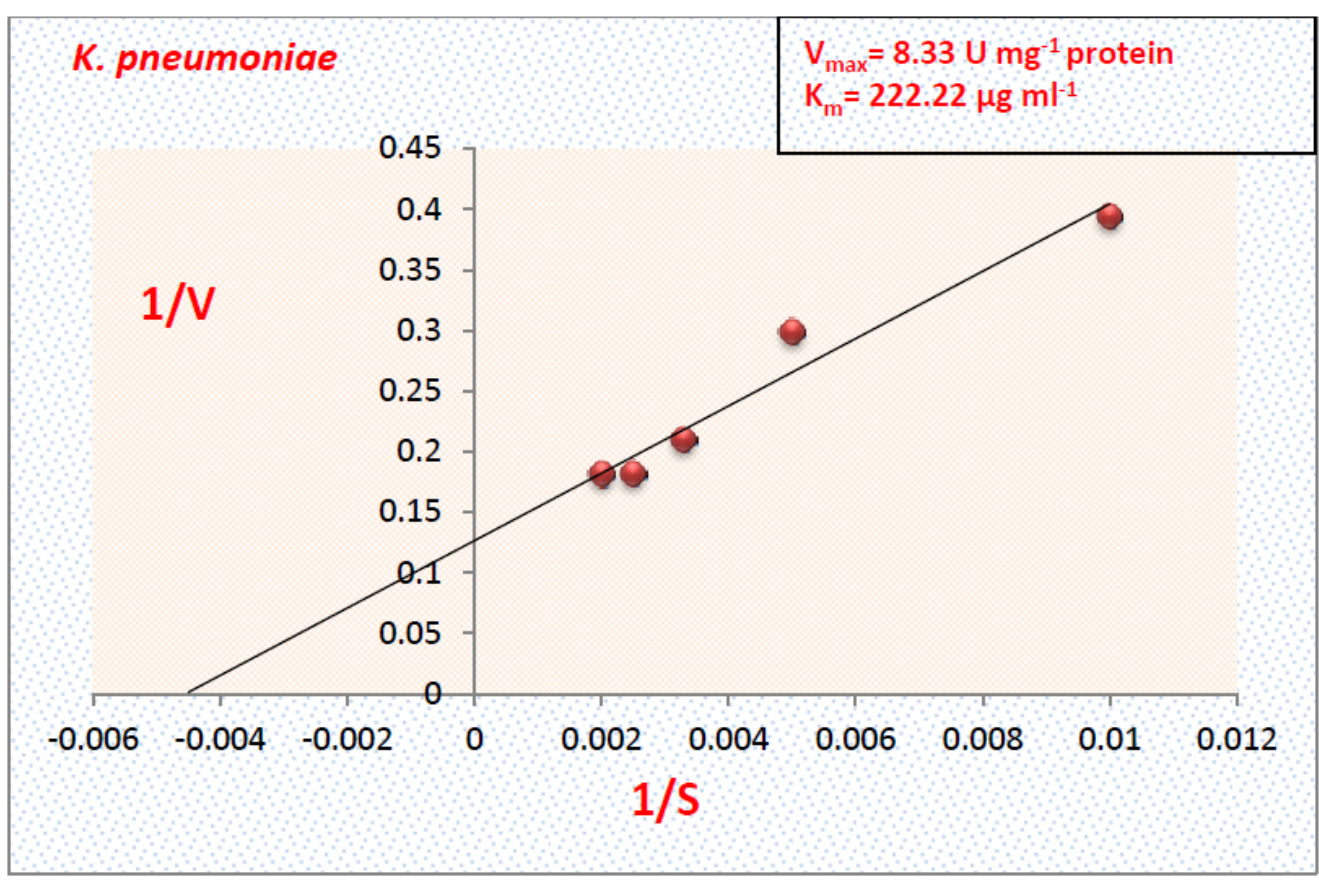

Fig.11 Effect of different enzyme concentrations on

$S$. sciuri and $K$. pneumoniae $\beta$-lactamase activity

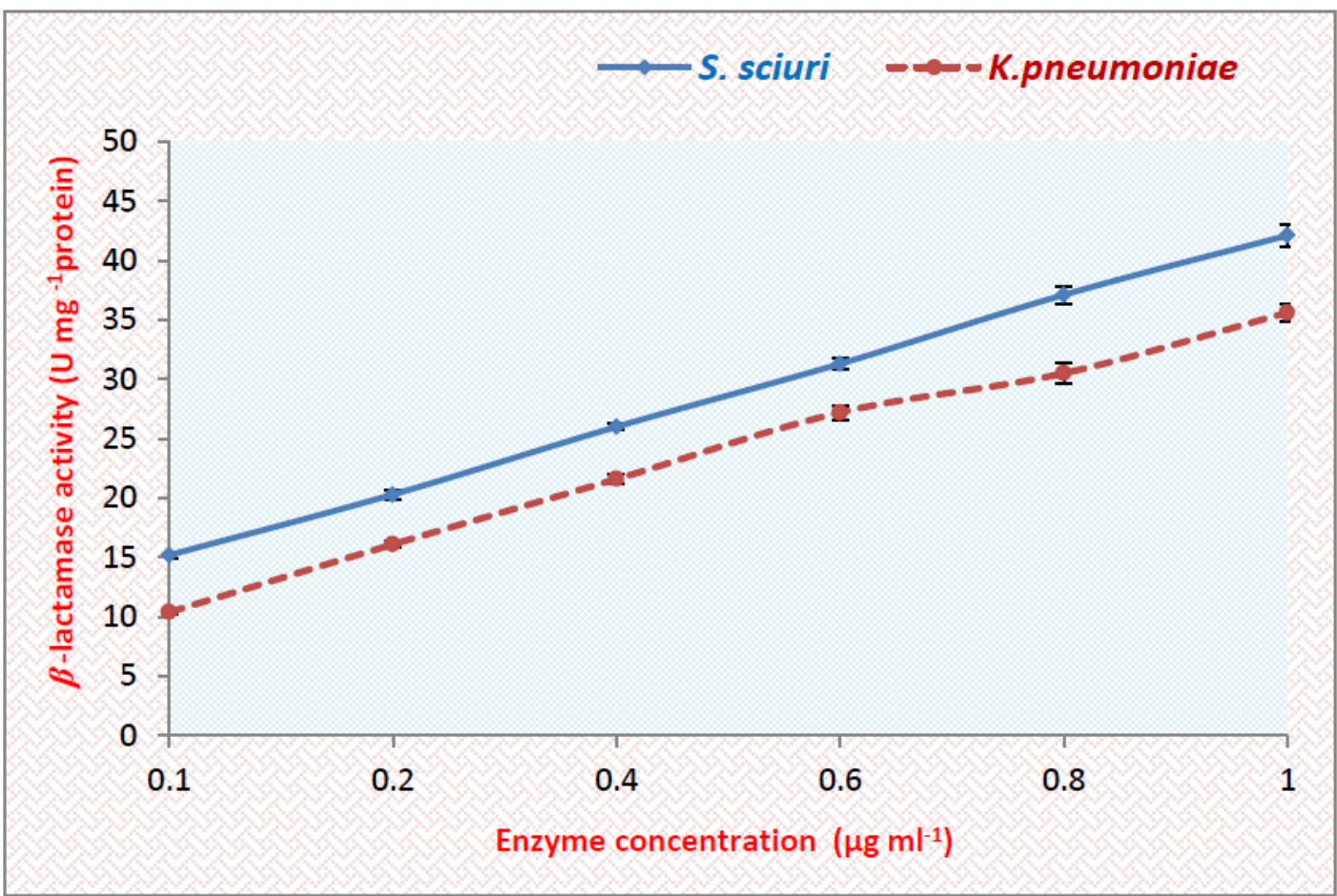


Fig.12 Effect of storage period on $S$. sciuri $\beta$-lactamase activity.

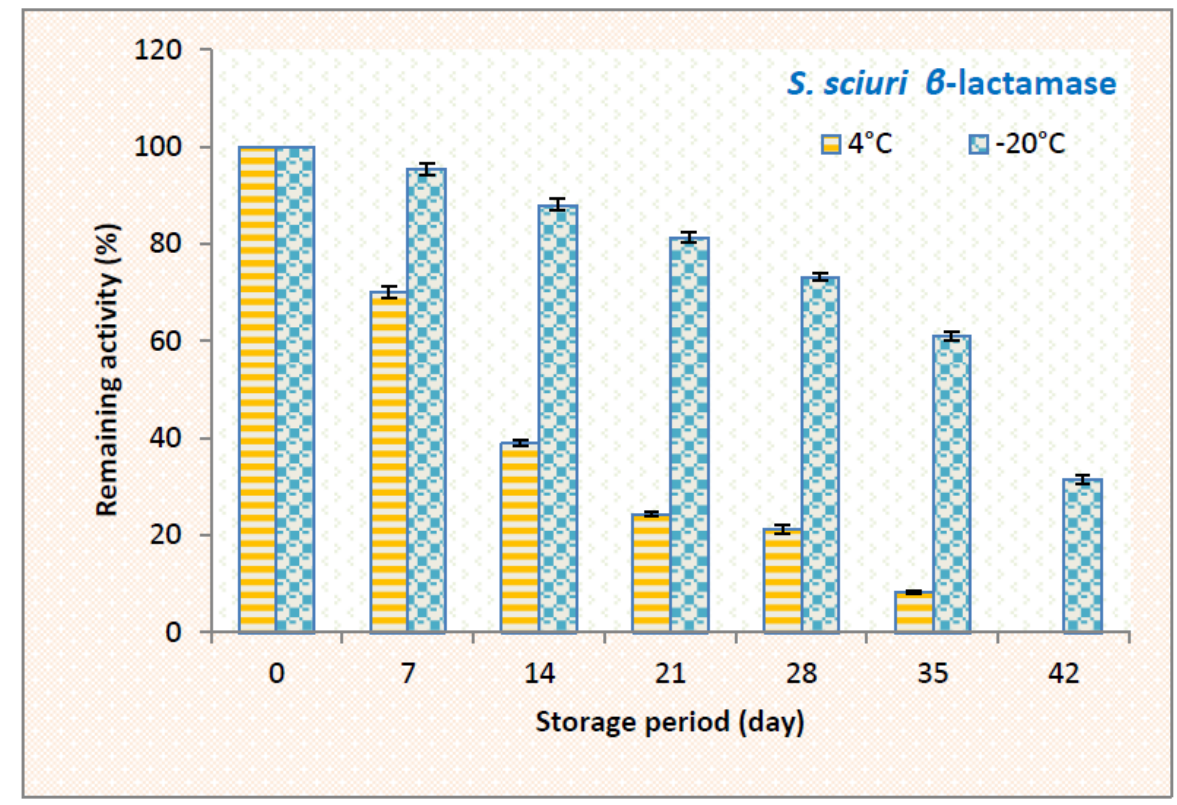

Fig.13 Effect of storage period on $K$. pneumoniae $\beta$-lactamase activity

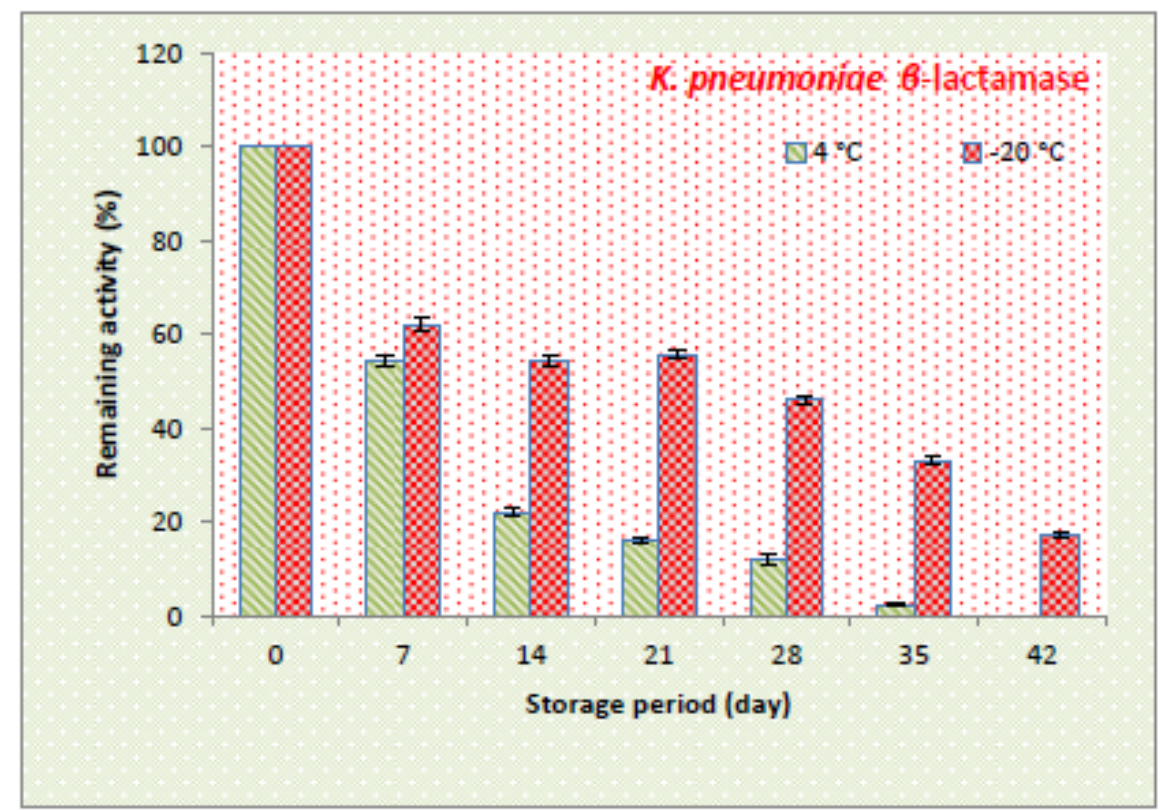

The purified enzyme is required for detailed biochemical and kinetic analysis to allow a deeper understanding of the mechanism of enzyme interaction. One of the principles for purification of an enzyme is to find a source of large quantities of the enzyme in a soluble form (El-Shora and Khalaf, 2008; El-Shora et al., 2008).

One of the aims of the present investigation was to purify the $\beta$-lactamase enzyme from $S$. sciuri and $K$. pneumoniae. Many procedures 
have been reported for the purification of $\beta$ lactamase (Ranade et al., 2013; Omeiri et al., 2014).

The enzyme was purified using ammonium sulfate, DEAE-Cellulose and Sephadex G-200 with specific activity of $70 \mathrm{U}$ mg-1protein and purification-fold of 46.7 of $S$. sciuri $\beta$ lactamase. In case of $K$. pneumoniae $\beta$ lactamase the specific activity of $100 \mathrm{U} \mathrm{mg}$ 1protein and purification-fold of 83.3.

The specific activity of $\beta$-lactamase from $S$. sciuri was $23.8 \mathrm{U}$ mg-1protein from $K$. pneumoniae with purification fold of 32.7 and yield of $47.04 \%$ (Al-Jumaily et al., 2009). Omeiri et al. (2014) reported a specific activity of $24.1 \mathrm{mg}$-1protein from $S$. aureus with purification fold of 102.3 and yield of 58.74\%. De Castillo et al. (2001) recorded specific activity of $13.7 \mathrm{U} \mathrm{mg}$-1protein for the enzyme from Neisseria gonorrhoeae.

SDS-PAGE showed that the molecular weight of S. sciuri $\beta$-lactamase was $30 \mathrm{KDa}$ whereas that from $K$. pneumonae was $28 \mathrm{KDa}$. Issa et al. (2010) recorded a molecular weight for $S$. aureus enzyme. However, the molecular weight of $35 \mathrm{kDa}$ was reported for $N$. gonorrhoeae $\beta$-lactamase by De Castillo et al. (2001). Al-Taai (2005) reported molecular weight of $35.5 \mathrm{kDa}$ for the enzyme from Proteus mirabilis. Furthermore, Al-Jumaily et al. (2009) recoded a molecular weight of 40 $\mathrm{kDa}$ for $K$. pneumoniae $\beta$-lactamase. Ranade et al. (2013) reported a higher molecular weight between 100 to $150 \mathrm{kDa}$ for E.coli $\beta$ lactamase.

The optimal $\mathrm{pH}$ values for purified $\beta$ lactamase activity were 7 and 6 from $S$. sciuri and $K$. pneumoniae, respectively. These results agree with those reported by Livermore and Corkill (1992) and Ranade et al. (2013) who found that the optimal $\mathrm{pH}$ values were 6-8 for $E$. coli. The optimum $\mathrm{pH}$ was 7.0-7.2 for purified Neisseria gonorrhoeae $\beta$-lactamase (De Castillo et al., 2001). Al-Jumaily et al. (2009) found that the optimal $\mathrm{pH}$ of $\beta$-lactamase activity from $K$. pneumoniae was 7.0. Issa et al. (2010) and Omeiri et al. (2014) reported optimal pH of 67 for $S$. aureus $\beta$-lactamase.

The optimal temperatures were $35{ }^{\circ} \mathrm{C}$ and $40^{\circ} \mathrm{C}$ for purified $\beta$-lactamase activity from $S$. sciuri and $K$. pneumoniae, respectively. The enzyme from $K$. pneumoniae was more stable than that from $S$. sciuri at $45^{\circ} \mathrm{C}$. These results agree with those reported by Al-Jumaily et al. (2009) and Ranade et al. (2013) who found that the optimal temperature of $\beta$-lactamase activity from $K$. pneumoniae was $35^{\circ} \mathrm{C}$. However, Issa et al. (2010) and Omeiri et al. (2014) reported optimal temperature range of $25-35^{\circ} \mathrm{C}$ for $S$. aureus $\beta$-lactamase activity. De Castillo et al. (1998) found optimal temperature of $37^{\circ} \mathrm{C}$ for Neisseria gonorrhoeae $\beta$-lactamase activity. It has been reported that $\beta$-lactamases are thermolabile proteins which inactivate rapidly by heat (De Castillo et al., 2001).

There is a continuous increase in the enzyme activity with the increase of penicillin $G$ as a substrate. The reaction of the enzyme will continue to increase continuously as long as some of the active sites of the enzymes are still able to breakdown the substrate. However, when all the active sites of the enzyme are full occupied then the rate of the enzyme reaction will reach the maximum rate (Vmax) and not well be affected by further increase of substrate concentration.

The results show $\mathrm{Km}$ value of $175.43 \mu \mathrm{g}$ ml-1 and Vmax of $7.69 \mathrm{U}$ mg-1 protein for S. sciuri $\beta$-lactamase. On the other hand, a $\mathrm{Km}$ value of $222.22 \mu \mathrm{g} \mathrm{ml}-1$ and $\mathrm{Vmax}$ of $8.33 \mathrm{U}$ mg-1 protein were recorded for $K$. pneumoniae $\beta$ lactamase. von Tigerstrom and Boras (1990) reported that $\mathrm{Km}$ for $\beta$-lactamase of Lysobacter enzymogenes was of $116 \mu \mathrm{g}$ ml-1. 
Also, Omeiri et al. (2014) reported that the $\mathrm{Km}$ and Vmax values of $111 \mu \mathrm{g}$ ml-1 and $16.66 \mathrm{U}$ mg-1 protein for $S$. aureus $\beta$ lactamase.

The enzyme from both bacteria expressed appreciable storage stability at $-20{ }^{\circ} \mathrm{C}$ compared to that at $4{ }^{\circ} \mathrm{C}$. In conclusion, this study showed several characteristics of $\beta$ lactamase from the two pathogenic bacteria which can be useful for controlling the enzyme activity.

\section{References}

Alekshun, M. N. and Levy, S. B. 2007. Molecular mechanisms of antibacterial multidrug resistance. Cell, 128:10371050.

Al-Jumaily, E. F.; Al-Taee, Z. A. S. and AlSafar, M. A. 2009. Purification and characterization $\beta$-lactamase produce from local isolate Klebsiella pneumoniae. Umm Salamah J. Sci., 6 (1): 50-60.

Al-Taai, H. R. R. 2005. Bacteriological, Biochemical and molecular study of Proteus mirabilis isolated from urinary tract infections in some hospitals of Baghdad city. MSc Thesis. Al Mustansiriya University.

Bush, K. and Jacoby, G. A. 2010. Updated functional classification of batalactamases. Antimicrob. Agents Chemother., 54 (3): 969-976.

De Castillo, M. C.; Islas, M. I.; Nader, O. M. and Ruiz-Holgado, A. B. 2001. Purification and characterizzation of $\beta$ lactamase from Neisseria gonorrhoeae from clinical samples. Revista Latinoamericana de Microbiologia, 43(2): 70-75.

De Castillo, M. C.; Sesma, F.; Nader, O. M. and Ruiz Holgado, A. P. 1998. Properties of $\beta$-lactamase from Neisseria gonorrhoeae. Mem. Inst .Oswaldo. Cruz., Rio de Janeiro, 93 (2): 237-241.

El-Shora, H. M. and Ashour, S.A. 1993. Biochemical characterization of L- asparaginase from Bacillus sp. Egypt. J. Environ. Sci. 6:105-120.

El-Shora, H.M. Khalaf, A. 2008. Activities and kinetic characteristics of glutamine synthetase from Penicillium cyclopium. Ann. Microbiol., 58: 691-696.

El-Shora, H. M. and Metwally, M. A. 2008. Production, purification and characterization of proteases from whey by some fungi. Ann. Microbiol., 58 (3): 495-502.

El-Shora, H. M., Youssef, M.M. and Khalaf, S. 2008.Inducers and Inhibitors of Laccase from Penicillium. Biotechnology, 7: 3542.

Gniadkowski, M. 2001. Evolution and epidemiology of extended-spectrum $\beta$ lactamases (ESBLs) and ESBLproducing microorganisms. Clinic. Microbiol. Infect., 7 (11): 597-608.

Hedberg, M.; Lindqvist, L.; Bergman, T. and Nord, C. E. 1995. Purification and characterization of a new $\beta$-lactamase from Bacteroides uniformis. Antimicrob.Agents Chemother., 39 (7): 1458-1461.

Helfaut, M. and Bonomo, R. 2005. Current challenges in antimicrobial chemotherapy: the impact of extendedspectrum beta-lactamases and Metallobeta-lactamases on the treatment of resistant Gram-negative pathogens. Curr. Opin. Pharmacol .; 5 (5): 452-458.

Issa, A.H.; Saeed, E.A. and Sucker, D.K. 2010. The isolated and purified $\beta$-lactamase from local isolate of Staphylococcus aureus. Al-Qadisiya J. Vet. Med. Sci., 9(1):11-20.

Laemmi, U. K. 1970. Cleavage of structural proteins during the assembly of the head of bacteriophage T4. Nature, 227 (5259): 680-685.

Livermore, D. M. 1995. Beta-Lactamases in laboratory and clinical resistance. Clinical Microbiology Reviews, 8 (4): 557- 584.

Livermore, D. M. and Corkill, J. E. 1992. Effects of $\mathrm{CO}_{2}$ and $\mathrm{pH}$ on inhibition of TEM-1 and other $\beta$-lactamases by 
penicillanic acid sulfones. Antimicrob. Agents Chemother., 36: 1870-1876.

Livermore , D. M. and Brown, D. F. J. 2001. Detection of $\beta$-lactamases - mediated resistance. Antimicrob. Agents Chemother., 48: 59-64.

Omeiri, M.; Holail, H. and Olama, Z. 2014. Purification and characterization of Staphylococcus aureus beta -lactamase from Lebanese community. Int. J. Curr. Microbiol. App. Sci., 3 (2): 527-535.

Palmer, T. 1995. Understanding enzymes. 4th Edition, Ellis Harwood Publisher, UK.
Ranade, Y. A.; Dharmadhikari, S. M. and Wadegaonkar, P. A. 2013. Screening, production, purification and characterization of beta-lactamase from uropathogenic E.coli. Eur. J. Exp. Biol., 3 (1): 434-442.

von Tigerstrom, R. and Boras, G. 1990. Betalactamase of Lysobacter enzymogenes: Induction, Purification and Characterization. J. Gen. Microbiol., 136 (3): 521-527.

\section{How to cite this article:}

Hamed M. El-Shora, Huda S. Al-Hayanni and Ahmed M. El-Shobaky. 2017. Characterization of $\beta$-Lactamase from Two Pathogenic Bacteria. Int.J.Curr.Microbiol.App.Sci. 6(6): 927-941. doi: https://doi.org/10.20546/ijcmas.2017.606.109 